\title{
Analysis of Factors Affecting the Quality of Local Government Financial Statements
}

\author{
Heylmi Umi Widaryani* ${ }^{* 1}$ and Kiswanto ${ }^{2}$ \\ ${ }^{1,2}$ Accounting Department, Faculty of Economics, Universitas Negeri Semarang
}

\begin{abstract}
ARTICLE INFO
\section{Article History:}

Received May $14^{\text {th }}, 2018$

Accepted March $3^{\text {th }}, 2020$

Available March 31 $1^{\text {th }}, 2020$

\section{Keywords:}

LKPD quality; organizational commitment;

SAKD effectiveness;

SPI effectiveness

ABSTRACT

Testing the determinants or factors that influence the quality of LKPD is the aim of this study. All State Civil Servants (ASN) working in 51 Regional Organization (OPD) of Klaten Regency were made as research populations. The entire population was only 83 respondents who were selected as samples with purposive sampling technique in their selection. Structural Equation Model (SEM) smartPLS is a analysis tool of research data. The results showed that the effectiveness Regional Financial Accounting System (SAKD), and the effectiveness Internal Control System (SPI) had a positive and significant effect while organizational commitment did not have a positive and significant effect on quality of local government financial reports. The effectiveness of SAKD has a positive and significant effect on the effectiveness of SPI. The effectiveness SAKD, and the effectiveness SPI have a positive and significant effect on organizational commitment. The results of the study also prove that the effectiveness SPI can mediate but organizational commitment cannot mediate the relationship of regional financial accounting system to the quality of LKPD. The effectiveness SAKD and the effectiveness SPI play an important role in the quality of LKPD is the conclusion of this study.
\end{abstract}

(C) 2020 Published by UNNES. This is an open access article under the CC BY license (http://creativecommons.org/licenses/by/4.0/)

\section{INTRODUCTION}

The increasing demand of society regarding a good and clean government management is a form of the dynamics of the public sector development. According to Rahmawati (2016) demand from the community have made the central \& local governments apply the principles of openness and accountability for the implementation of good governance. Noviyanti (2016) stated that all accountability activities of the mandate holder (government) to the trustee (the people) are called accountability in the public sector. One of the accountabilities of the local government is to make a financial report (LK).

Presenting a good LK that must be in accordance with Government Accounting Standards (GAS). In addition to GAS, the presentation of financial statements must be high quality. Several normative measures are listed in PP No. 71 of 2010 concerning Government Accounting Standards namely, relevant, reliable, comparable and understandable. However, the fact is although the quality of LKPD in 2016 improved from 2015, but

\footnotetext{
*E-mail:heylmi084@gmail.com

_Address: L2 Building 2nd floor, Campus Sekaran, Gunungpati, Semarang, Indonesia, 50229
}

there were 23 out of 537 (4\%) LKPD which opinions dropped $2 \%$ lower than in 2016. One of them is Klaten Regency which experienced a decline in opinion (IHPS I in 2017).

Research gap also occurs on research variable of regional financial accounting system as evidenced by Ratifah (2012); Evicahyani (2016); Juwita (2013); and Sanjaya (2017) has a positive effect on the quality of local government financial statements. This is in contrast to Setyowati et al.(2016) and Rahmadani (2015) who did not find the relationship between the regional financial accounting system and the quality of local government financial statement.

Knowing empirically the determinants or factors that influence the quality of LKPD is the purpose of this study. The originality of this research is the regional financial accounting system variable which has inconsistent results in the previous studies so it needs to be re-examined. In addition, it lies in the research model that uses internal control system variable and organizational commitment as intervening variable where in the previous studies none used these variables as intervening variables. Stewardship theory and Goal-setting theory are the Grand theories in this research. The meaning of "service attitude" in psychology and sociology is the 
root of stewardship theory. The definition of stewardship theory is the attitude of employees / managers who are motivated to do work to achieve the vision and mission of the organization not for personal gain (Donaldson, 1997).

Goal-setting theory is described by a relationship between the purpose and performance to the work done (Locke, 1968). Employees who know or understand the goal of the organization will affect its performance; it is a basic concept of this theory. Goal-setting theory shows that achieving vision and mission (goals) is an individual commitment (Robbins, 2008). Individual attitudes derived from individual ideas or intentions and goals are considered as a goal or performance to be achieved by someone.

Qualified financial statements are those that can benefit the community and can be used as a basis for decision making, therefore a good accounting system is needed and is in accordance with GAS in making LK by the government. In accordance with the stewardship theory which explains leaders and all government employees as stewards are required to provide guarantees for financial statements that have elements of clarity, consistency, trustworthiness, and can be compared to stakeholders as principals. In connection with this, the financial statements produced by having these elements, makes financial statements useful in decision-making. This is in line with research conducted by Ratifah (2012), Juwita (2013) and Evicahyani (2016) where SAKD has a positive and significant effect on the quality of LKPD.

\section{$\mathrm{H}_{1}$ : The effectiveness of SAKD has a positive and significant effect on the quality of LKPD.}

Accounting system is part of the internal control system. When the accounting system is implemented properly, the information provided can be presented in accordance with planned timeliness and allows corrective action to be taken as a form of internal control in a timely manner and communication can be carried out openly and effective with internal supervisors in giving input. Thus, when the accounting system is running effectively, the implementation of internal control can also be applied effectively as well. Stewardship theory also explains that the duties and functions of leaders and all government employees as stewards are to serve, work responsibly, and at the same time provide the best guarantee for all affairs delegated to him to achieve the public interest as principals. The existence of a good accounting system will improve the internal control system, so that the duties and functions of stewards in serving are more optimal.

\section{$\mathrm{H}_{2}$ : The effectiveness of SAKD has a positive and significant effect on the effectiveness of SPI.}

Accounting system has the role of adding information value to an the accounting process of an organization. Accounting system also speeds up the process for producing financial reports and overcoming human weaknesses in data processing (Sori, 2009). There are several factors that make the system run well, among others, the success of a system apart from the techni- cal mastery factor also comes from the behavioral factor of the individual as the user of the system.. Setiyawati (2013) in managing the accounting information system, placing the system and human resources at the forefront needs to be done by the local government. A well-implemented accounting system makes employees believe that there are no irregularities in the system. Employees become more loyal and feel that the agency is worth to be a place to work and can feel a part of the family in the agency. In accordance with Goal-setting theory, which shows that achieving the vision and mission (goals) is an individual commitment (Robbins, 2008). A good performance of an individual is an indicator of high commitment in achieving organizational goals.

\section{$\mathrm{H}_{3}$ : The effectiveness of SAKD has a positive and significant effect on organizational commitment}

The accounting process in producing reliable financial reports requires an internal control system (SPI) that gives trust in the effectiveness and efficiency of the process. The running of an effective SPI makes LKPD is more qualified because it prevents the risk of irregularities in the financial statements.

Organization will not be fully effective without good internal control (Afiah, 2015). In addition, SPI also prevents irregularities in preparing financial statements. Upabayu (2014) increased reliability and objectivity of information is the purpose of the existence of SPI besides it also can prevent inconsistencies. Internal control system will run efficiently and effectively if individuals prefer the interests of the organization, in accordance with stewardship theory which shows that people who work in an organization tends to prioritize the interests of the organization rather than their own interests.

Sutrisno (2014) proved that SPI has a positive effect on the quality of LKPD. This research is in line with research conducted by Surastiani (2015) and Faishol (2016) which states that local government internal control has a positive and significant effect on the quality of local government financial statements.

\section{$\mathrm{H}_{4}$ : The effectiveness of SPI has a positive and sig- nificant effect on the quality of LKPD}

Good employee commitment is needed to produce qualified financial reports. Increasing the commitment / involvement of members is one way to improve regional financial management so as to producing qualified reports. Good commitment makes employees feel happy to work well and assume that the organization has the right to get loyalty from himself so that in producing financial reports for the organization to be more optimal. Streers (1977) stated one's involvement in organization is able to reflect the relative strength of an individual organizational commitment. The higher the organizational commitment, in processing accounting information will be more qualified. In accordance with Goal-setting theory which shows that achieving the vision and mission (goals) is an individual commitment (Robbins, 2008). An individual opposes the existence of unclear goals and is always willing to do the best (Verbeeten, 2008). This is also in line with research con- 
ducted by Setiyawati (2013) where organizational commitment has a significant positive effect on the quality of financial statements.

\section{H5: Organizational commitment has a positive and significant effect on the quality of LKPD.}

The set of procedures that are influenced by technology and human resources and designed for the achievement of organizational goals is an understanding of internal control system. Tuti (2014) explained that directing, supervising, measuring organizational resources, and preventing or detecting embezzlement are the main objectives of SPI. One of the implementations of internal control is when a leader firmly resolves a violation of policies, procedures, or rules regarding employee behavior, behavioral procedures or rules of make employees feel fair if there is a violation. Employees will feel comfortable working at the place where it will increase employee work loyalty. Thus, if internal control system is good, it will increase organizational commitment, employees will be able to work serving with full responsibility and provide the best guarantee.

In accordance with Goal-setting theory which shows that achieving the vision and mission (goals) is an individual commitment (Robbins, 2008). A good performance of an individual is an indicator of high commitment in achieving organizational goals. Thus, with an effective control system will increase employee commitment.

\section{$\mathrm{H}_{6}$ : The effectiveness of SPI has a positive and sig- nificant effect on organizational commitment}

The existence of a good SPI in the organization encourages employees to compile and present information using the accounting system effectively also in accordance with SAP making the financial statements made more qualified. A belief in the reliability of the presentation of financial statements, compliance with all existing regulations, and the operational effectiveness and efficiency of the superiors and all state civil servants to the public are guarantees given by the government in the presence of SPI. Employees will adhere to an accounting system with adequate internal control so that financial information is more qualified to be presented. In accordance with stewardship theory, which explains the duties and functions of leaders and all government employees as stewards are to serve, work with full responsibi- lity, and at the same time provide the best guarantee for all affairs delegated to them to achieve the public interest as principals. The existence of a good SPI in the organization encourages the state civil servants to provide good and honest financial information, which is related to the accounting system. In addition, the existence of a good SPI will prevent the occurrence of serving in favor of one person or group of people for individual interests. Thus, through SPI, the accounting system will also be effectively applied to present good or qualified LKPD. Evicahyani (2016) has also proven that internal control system can mediate the effect of the local financial management system on the quality of financial statements.

\section{$\mathrm{H}_{7}$ : The effectiveness of SAKD has a positive and significant effect on the quality of LKPD through SPI}

High commitment from the state civil servants is needed in implementing and establishing SAKD policies. High commitment makes employees have a sense of loyalty in working in organizations so that in running the existing regional financial accounting system in the government will be utilized to the fullest and individuals will comply with all the laws and regulations that have been set if each employee has a good commitment. Thus, it is needed a commitment to run the accounting system in accordance with existing regulations in order to produce good quality LKPD.

In accordance with Goal-setting theory which shows that achieving the vision and mission (goals) is one's commitment. This means that when having high commitment in achieving the objectives of the accounting system that is presenting a qualified financial report will be easier.

\section{$\mathrm{H}_{8}$ : The effectiveness of SAKD has a positive and significant effect on the quality of LKPD through the implementation of organizational commitment}

\section{RESEARCH METHOD}

Primary data obtained directly from the source were used in this quantitative study. Hypothesis study was a research design that aims to analyze, describe, and obtain empirical evidence of the pattern of relationships between the effectiveness of SAKD, the effectiveness of SPI, and organizational commitment to the quality

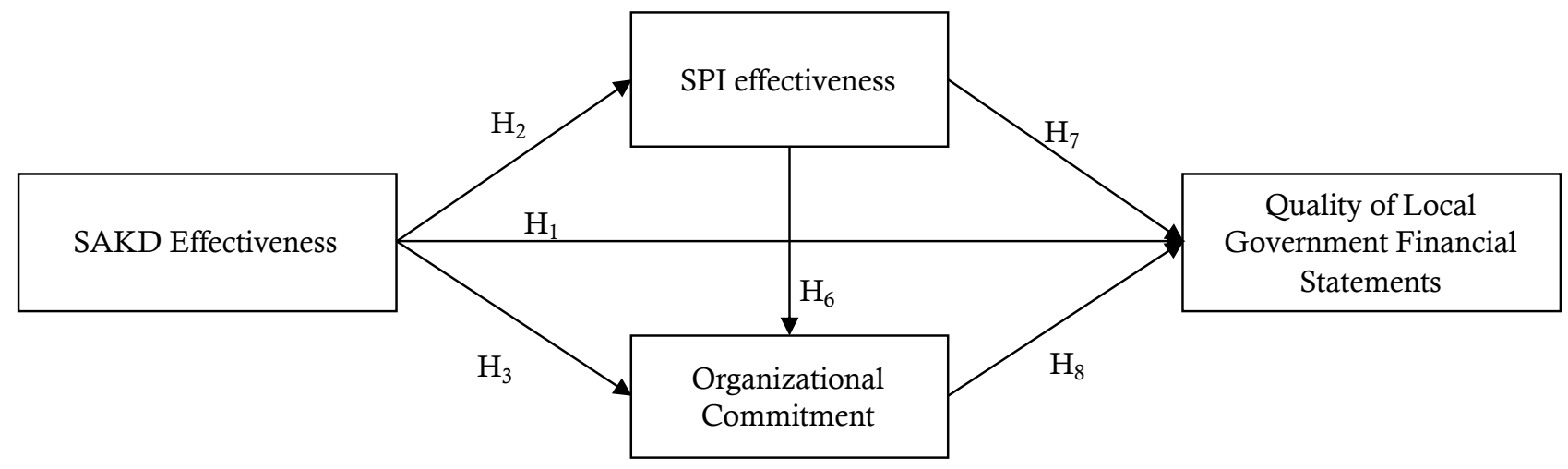

Figure 1. Theoretical Framework 
Table 1. Operational Definition and Measurement of Variables

\begin{tabular}{cll}
\hline No & Variable Definition & Measurement Indicator \\
\hline 1 & The Quality of Local Government Financial Statements & 1. Relevant \\
& (LKPD) is normative measures that need to be realized in & 2. Reliable \\
accounting information so that they can meet their objec- & 3. Comparable \\
tives. (PP No 71 of 2010) & 4. Understandable (Suliyantini, 2016 and \\
& Rizkyana, 2016)
\end{tabular}

2 The Regional Financial Accounting System (SAKD) in- 1. Conformity with the Financial Accounting cludes a series of procedures ranging from the process of System data collection, recording, summarizing, to financial report- 2. Procedure for recording transactions ing that can be done manually or using a computer applica- 3. Making financial statements tion. (Permendagri No 13 Tahun 2006) 4. (Permadi, 2013 and Rizkyana, 2016)

3 Internal Control System (SPI) is an integral process in ac- 1. Control environment tions and activities carried out continuously by the leader- 2. Risk assessment ship and all employees to provide sufficient confidence in 3. Control activities the achievement of organizational goals through effective 4. Information and communication and efficient activities, the reliability of financial reporting, 5. Monitoring securing state assets, and compliance with laws and regula- 6. (Government Number 60 Year 2008 and tions. (PP No 60 of 2008) Suliyantini, 2016)

4 Organizational Commitment (KO) is the ability and willing- 1 . Affective commitment ness to align personal behavior with the needs, priorities, and 2. Continuance commitment goals of the organization. (Natalie J Allen and John P Meyer 3. Normative commitment in Dunham, et al., 1994) (Ratifah, 2012)

of financial statements. All State Civil Servants (ASN) who work in the entire Klaten Regency OPD were the study population. The entire population was only 83 respondents who were selected as samples by purposive sampling technique in their selection. Consisting of 51 OPDs, there were 2 respondents each, namely the head of the finance department and financial staff who meet the criteria for carrying out financial accounting / administrative functions and have worked for more than 1 year. Thus, the sample amounted to 102 respondents. However, there were 13 questionnaires that did not return and 3 incomplete questionnaires so that only 83 samples could be processed.

The operational definitions and measurement of variables can be seen in the following Table 1. Primary data in this study were collected using a questionnaire technique or questionnaire list provided directly to respondents. The measurement scale for the questionnaire is using a Likert scale of 1 to 5 , consisting of number 1 (strongly disagree), number 2 (disagree), number 3 (doubtful), number 4 (agree), number 5 (totally agree). Structural Equation Model (SEM) smartPLS is an analysis tool of research data.

\section{RESULTS AND DISCUSSIONS}

The results of the descriptive statistical analysis of the respondents will be illustrated in the following Table 2. The questionnaire given to respondents only return 86 questionnaires, 16 questionnaires are not returned and 3 questionnaires are not filled in so that it is considered invalid and not included in the analysis. Therefore, there are 83 questionnaires used in the analysis of this study. The result of the inferential analysis using
Table 2. Characteristics of Respondents

\begin{tabular}{clr}
\hline No & \multicolumn{1}{c}{ Information } & Total \\
\hline 1. & Position : & \\
& Echelon IV (Head of finance) & 37 \\
& Finance staff & 46 \\
& Total & 83 \\
\hline 2. & Sex: & 47 \\
Male & 36 \\
& Female & 83 \\
Total & \\
\hline 3. & Long Served: & 29 \\
1-5 years & 42 \\
6-10 years & 12 \\
& >10 years & 83 \\
Total &
\end{tabular}

4. Education Level:

High School/ Equivalent 9

D3 8

S1 48

S2 18

Total 83

5. Educational Major:

Accounting 18

Management 29

Agriculture 2

Mathematics and Natural Resources 2

Others 23

f. SLTA / Equal 9

Total 83

Source: Primary data processed, 2018 
Table 3. Summary of Hypothesis Test Results

\begin{tabular}{|c|c|c|c|c|c|c|}
\hline No & Hypothesis & Information & $\begin{array}{c}\text { Coefficient } \\
\text { value }\end{array}$ & $\begin{array}{c}\text { P- } \\
\text { Values }\end{array}$ & $\alpha$ & Results \\
\hline 1. & $\mathrm{H}_{1}$ & $\begin{array}{l}\text { The effectiveness of SAKD has a positive and signifi- } \\
\text { cant effect on the quality of LKPD }\end{array}$ & 0.391 & 0.001 & 0.05 & Accepted \\
\hline 2. & $\mathrm{H}_{2}$ & $\begin{array}{l}\text { The effectiveness of SAKD has a positive and signifi- } \\
\text { cant effect on the quality of LKPD }\end{array}$ & 0.345 & 0.007 & 0.05 & Accepted \\
\hline 3. & $\mathrm{H}_{3}$ & $\begin{array}{l}\text { The effectiveness of SAKD has a positive and signifi- } \\
\text { cant effect on organizational commitment }\end{array}$ & 0.210 & 0.145 & 0.05 & Rejected \\
\hline 4. & $\mathrm{H}_{4}$ & $\begin{array}{l}\text { The effectiveness of SPI has a positive and significant } \\
\text { effect on the quality of LKPD }\end{array}$ & 0.309 & 0.008 & 0.05 & Accepted \\
\hline 5. & $\mathrm{H}_{5}$ & $\begin{array}{l}\text { Organizational commitment has a positive and sig- } \\
\text { nificant effect on the quality of LKPD }\end{array}$ & 0.139 & 0.203 & 0.05 & Rejected \\
\hline 6. & $\mathrm{H}_{6}$ & $\begin{array}{l}\text { The effectiveness of SPI has a positive and significant } \\
\text { effect on organizational commitment }\end{array}$ & 0.101 & 0.318 & 0.05 & Rejected \\
\hline 7. & $\mathrm{H}_{7}$ & $\begin{array}{l}\text { The effectiveness of SAKD has a positive and signifi- } \\
\text { cant effect on the quality of LKPD through the inter- } \\
\text { nal control system }\end{array}$ & 0.272 & 0.002 & 0.05 & Accepted \\
\hline 8. & $\mathrm{H}_{8}$ & $\begin{array}{l}\text { The effectiveness of regional SAKD has a positive } \\
\text { and significant effect on the quality of LKPD through } \\
\text { organizational commitment }\end{array}$ & - & - & 0.05 & Rejected \\
\hline
\end{tabular}

SEM outer model test, first test the validity seen from the loadings value. The loadings values of all constructs are more than 0.5 , then all constructs are said to be valid. Second, testing the reliability seen from the value of Composite Reliability, which is $0.928 ; 0.926 ; 0.907$; 0.859 . These values are more than 0.7 , so it can be said that all constructs are reliable.

The result of inner model test can be seen from the $R^{2}$ value that is LKPD quality variable is 0.143 which means that the effect of SAKD effectiveness, SPI effectiveness and organizational commitment in explaining LKPD quality variable is $14.3 \%$ and the remaining $85.7 \%$ is influenced by variables other than the research model. The $\mathrm{R}^{2}$ value of the SPI effectiveness is 0.119 which means that the effect of the SAKD effectiveness variable in explaining the SPI variable is $11.9 \%$. The value of $\mathrm{R}^{2}$ for organizational commitment variable is 0.069 which means that the effect of SAKD effectiveness and SPI effectiveness in explaining organizational commitment variable is $6.9 \%$. All $\mathrm{R}^{2}$ values are included in the weak category.

\section{The Effect of SAKD Effectiveness on LKPD Quality}

The effectiveness of SAKD has a positive and significant effect on the quality of LKPD. The effectiveness of the accounting system in accordance with the rules of the Law will increase the quality of financial statements. On the contrary, if the financial statements are made not in accordance with SAP, then the quality of financial statements will be low. The implementation of regional financial accounting systems in accordance with the rules of the Law is very necessary in the preparation of financial statements, this is needed to make LK that meets the normative size / qualitative characteristics of reporting and can be free from material misstatement. In accordance with stewardship theory which explains that the government as a public sector organization has the responsibility in carrying out good governance as a form of accountability for the performance of the government, then the government needs to provide information in the form of LKPD. The result of this study is the same as the research conducted Ratifah (2012), Evicahyani (2016) as well as Juwita (2013).

\section{The Effect of SAKD on the Effectiveness of SPI}

The effectiveness of SAKD has a positive and significant effect on the effectiveness of SPI. This means, when the accounting system is implemented well that is in accordance with SAP and transactions are supported by transaction evidence, then in internal control where the risk analysis of the occurrence of violations of accounting systems and procedures decrease. In addition, when the accounting system is good, information can be presented according to planned timeliness and allow corrective action to be taken appropriately and communication can be done properly or openly and effectively with internal supervisors in providing input as a form of internal control. This is consistent with stewardship theory, which explains that the duties and functions of leaders and all government employees as stewards are to serve, work responsibly, and at the same time provide the best guarantee for all matters delegated to them to achieve the public interest as principals. With the existence of a good accounting system, it will improve its internal control system so that it serves to provide better assurance and full responsibility.

\section{The Effect of SAKD on Organizational Commitment}

The effectiveness of SAKD has no positive and significant effect on organizational commitment. This means, no matter how well the implemented regional financial accounting system will not affect the organizational commitment. Although organizations always improve the existing accounting system so that employees are working comfortable and can increase their commitment. However, if the employees do not have the will / motivation from themselves to work well, then no matter how good the system does not affect the organizational commitment in accordance with motivational 
theory where things that encourage to achieve / work well come from themselves. The result of this study is not in line with Goal-setting theory which shows that achieving the vision and mission (goals) is a commitment of a person.

\section{The Effect of Effectiveness of SPI on LKPD Quality}

The effectiveness of SPI has a positive and significant effect on the quality of LKPD. The result of this study is in accordance with stewardship theory where the government tries to implement an internal control system in accordance with existing rules. The interests of the organization are also prioritized over the interests of individuals, this makes the existing internal control system in local government organizations can run effectively and efficiently,) so that the form of government accountability for performance made in financial statements has a good report quality. Internal control in the central and regional governments that are guided by the regulation number 60 of 2008 concerning the internal control system (SPI) where SPI provides adequate confidence in the achievement of efficiency and effectiveness in carrying out the accounting process, especially in achieving good qualified financial statements that is meeting all reporting criteria in accordance with existing rules. The result of this study supports the research that have been done (Widari, 2017), (Surastiani, 2015) as well as (Faishol, 2016).

\section{The Effect of Organizational Commitment on LKPD Quality}

Organizational commitment does not have a positive and significant effect on the quality of LKPD. This means, for high organizational commitment does not affect in improving the quality of financial statements. Because even though employees have high commitment and will affect their performance, the facts that occur in the field, namely in internal factors, there are still many employees who do not come from accounting competencies. The data shows that only $21.7 \%$ of employees have accounting competencies other than that outside accounting competencies. So that despite having high commitment but not accompanied by adequate competence makes the quality of the Klaten District LKPD poorly due to the lack of understanding of producing financial information that is in accordance with the existing normative measures. This is contrary to Goalsetting theory which shows that achieving the vision and mission (goals) is one's commitment.

\section{The Effect of the Effectiveness of SPI on Organiza- tional Commitment}

The effectiveness of SPI has no positive and significant effect on organizational commitment. Internal control system does not affect organizational commitment because an effective internal control system does not necessarily increase an organizational commitment. Employees are more motivated by the existence of an awareness that arises due to external factors. Based on work patterns, employees tend to be motivated to work with rewards that are in accordance with the results they have achieved in accordance with the theory of two factors, namely in doing something comes from internal oneself or from external (Sudrajat, 2008). This is not in accordance with stewardship theory which explains that the duties and functions of leaders and all government officials as stewards are to serve, work with full responsibility, and at the same time provide the best guarantee for all affairs delegated to them to achieve the public interest as principals.

\section{The Effect of SAKD on the Quality of LKPD through the Internal Control System}

The indirect effect result of SPI variable can mediate the relationship between SAKD effectiveness and LKPD quality. The existence of a good SPI in the organization encourages the state civil servants to present information according to the facts related to the accounting system. In addition, the existence of a good SPI will prevent the occurrence of serving in favor of one person or group of people for individual interests. This is consistent with stewardship theory, which explains that the duties and functions of the leaders and all government officials as stewards are to serve, work with full responsibility, and at the same time provide the best guarantee for all affairs delegated to him to achieve the public interest as principals. This study supports research conducted by Evicahyani (2016) which has also proven that the internal control system can mediate the effect of the regional financial management system on the quality of LKPD.

\section{The Effect of SAKD Effectiveness on LKPD Quality through Organizational Commitment}

Based on the test results, the indirect effect of organizational commitment cannot mediate the relationship between the effectiveness of SAKD and the quality of LKPD. Low or high organizational commitment does not affect the accounting system, one of the causes is SAKD is a government policy in making financial statements that have been arranged in PP No.65 of 2010 regarding the Regional Financial Information System, so that it has become a mandatory thing for the local government. The result of this study contradicts Goalsetting theory which states that the higher the level of individual commitment to the organization will make the performance of government organizations be increased in achieving organizational goals.

\section{CONCLUSIONS}

The conclusion of the discussion is that the SAKD effectiveness variable and the effectiveness of SPI have a significant positive effect while organizational commitment does not have a significant positive effect on the quality of LKPD. The internal control system mediates while the organizational commitment cannot mediate the relationship of the regional financial accounting system to the LKPD quality. 
Suggestion from this research are for Regional Apparatus Organizations (OPD) to improve internal control systems by setting competency standards for each task and function in each of the existing positions because there are still competencies other than accounting that handle the financial department. In addition, OPD must conduct a complete fraud / other risk analysis of fraud in the accounting system because there are still differences with SAP in the accounting system. The next research is not to use intervening variable of organizational commitment, because based on the results of this study organizational commitment cannot mediate the effect of the effectiveness of SAKD on the quality of LKPD. It can also use research objects other than Klaten Regency to be more varied.

\section{REFERENCES}

Afiah, N. N. \& P. C. A. (2015). The Effect of The Implementation of Government Internal Control System (GICS) on The Quality of Financial Reporting of The Local Government and Its Imapact on The Principles of Good Governance. Elsevier, 211(1), 811-818.

Donaldson. (1997). Toward A Stewardship Theory of Management. Academy of Management Review, 22(1), 20-47.

Evicahyani, S. I. \& N. D. S. (2016). Analisis Faktor-Faktor yang Mempengaruhi Kualitas laporan Keuangan Pemerintah Daerah Kabupaten Tabanan. E-Jurnal Ekonomi dan Bisnis Universitas Udayana, 3(5), 403-428.

Faishol, A. (2016). Pengaruh Sistem Pengendalian Intern Terhadap Kualitas Laporan Keuangan (Studi Kasus Pada Satuan Kerja Perangkat Daerah Pemerintah Kabupaten Lamongan). Jurnal Penelitian Ekonomi dan Akuntansi, $I(3), 205-212$.

Juwita, R. (2013). Pengaruh Implementasi Standar Akuntansi Pemerintahan dan Sistem Informasi Akuntansi Terhadap Kualitas Laporan Keuangan. Trikonomika, 12(2), 201-214.

Noviyanti, N. A. \& K. (2016). Pengaruh Karakteristik Pemerintah Daerah, Temuan Audit BPK Terhadap Kinerja Keuangan Pemerintah Daerah. Accounting Analysis Journal, 5(1), 1-10.

Rahmadani, S. (2015). Pengaruh Kompetensi Sumber Daya Manusia, Sistem Akuntansi Keuangan Daerah, Pemanfaatan Teknologi Informasi Dan Sistem Pengendalian Intern Terhadap Kualitas Laporan Keuangan Pemerintah Daerah (Studi Pada SKPD Kabupaten
Pasaman Barat). JOM Fekon, 2(2), 1-15.

Rahmawati, R. A. \& A. M. (2016). Faktor-Faktor Yang Mempengaruhi Transparansi Pelaporan Keuangan Pemerintah Daerah. Accounting Analysis Journal, 5(2), 122-130.

Ratifah, I. (2012). Komitmen Organisasi Memoderasi Pengaruh Sistem Akuntansi Keuangan Daerah terhadap Kualitas Laporan Keuangan. Trikonomika, 11(1), 2939.

Robbins dan Judge. 2008. Perilaku Organisasi Buku 1. Jakarta : Salemba Empat

Sanjaya, A. (2017a). Pengaruh Penerapan Standar Akuntansi Pemerintahan, Sistem Pengendalian Intern, Sistem Akuntansi Keuangan Daerah. JOM Fekon, 4(1), 366380 .

Setiyawati, H. (2013). The effect of Internal Accountants ' Competence, Managers ' Commitment to Organizations and the Implementation of the Internal Control System on the Quality of Financial Reporting. International Journal of Business and Management Invention, 2(11), 19-27.

Setyowati, L., Isthika, W., \& Pratiwi, R. D. (2016). FaktorFaktor Yang Mempengaruhi Kualitas laporan Keuangan Pemerintah Daerah Kota Semarang. Jurnal Bisnis Dan Ekonomi, 20(2), 179-192.

Sori, Z. M. (2009). Accounting Information Systems (AIS) and Knowledge Management : A Case Study. American Journal of Scientific Research, 4(4), 36-44.

Surastiani, D. P. \& B. D. H. (2015). Analisis faktor-Faktor Yang Mempengaruhi Kualitas Informasi Laporan Keuangan Pemerintah Daerah. Jurnal Dinamika Akuntansi, 7(2), 139-149.

Tuti, H. (2014). Pengaruh Sistem Pengendalian Intern terhadap Kualitas Laporan Keuangan. Study \& Accounting Research, 9(1), 1-14.

Upabayu, I. P., Mahaputra, R., \& Putra, I. W. (2014). Analisis Faktor-Faktor yang Mempengaruhi Kualitas Informasi Pelaporan Keuangan Pemerintah Daerah. E-Jurnal Akuntansi Universitas Udayana, 2(8), 230-244.

Verbeeten, F. H. M. (2008). Performance management practices in public sector organizations Impact on performance. Accounting, Auditing \& Accountability Journal, 21(3), 427-454.

Widari, L. \& S. (2017). Pengaruh Sistem Pengendalian Internal Pemerintah Dan Komitmen Organisasi Terhadap Kualitas Laporan Keuangan Daerah. Jurnal Ilmiah Ilmu Ekonomi, 5(10), 117-126.

Yuliani, N. L., \& Agustini, R. D. (2016). Faktor yang Mempengaruhi Kualitas Laporan Keuangan Pemerintah Daerah. JOM Fekon, 14(3), 56-64 